\title{
Integration of Geophysical and Geotechnical Soil Characteristics for Local Site Seismic Design in Georgia
}

\author{
N. Jorjiashvili, M. Gigiberia, I. Shengelia, M. Otinashvili \\ Ilia State University, Tbilisi, Georgia \\ Email: nato_jorjiashvili@iliauni.edu.ge
}

How to cite this paper: Jorjiashvili, N., Gigiberia, M., Shengelia, I. and Otinashvili, M. (2018) Integration of Geophysical and Geotechnical Soil Characteristics for Local Site Seismic Design in Georgia. Open Journal of Earthquake Research, 7, 108-123. https://doi.org/10.4236/ojer.2018.72007

Received: April 27, 2018

Accepted: May 28, 2018

Published: May 31, 2018

Copyright ( 92018 by authors and Scientific Research Publishing Inc. This work is licensed under the Creative Commons Attribution International License (CC BY 4.0).

http://creativecommons.org/licenses/by/4.0/

(c) (i) Open Access

\begin{abstract}
Recently, number of new constructions and engineering projects increased in Georgia, especially in Tbilisi, the capital of Georgia. Because of significant seismic activity of Caucasus region, seismic hazard assessment is very important issue for seismic-designing of engineering projects. Due to modern building codes, complex study of the local area is crucial for proper design of any type of constructions. Among them, following studies should be performed: probabilistic seismic hazard assessment, geological, geotechnical, geophysical, etc. After that, all information should be merged to each other and taken into account while designing of the project. In this paper, location of one construction site was selected as an application of complex study in order to show how can be merged different studies to each other. At the beginning, geological survey (well drilling) and geotechnical studies including laboratory tests were performed. Then geophysical profiling and downhole tests in wells were done by obtaining direct and shear wave velocities including estimation of physical-mechanical parameters. Next, probabilistic seismic hazard assessment and site-depended seismic hazard assessment were performed based on all information obtained by different studies. As a result, influence of local soil amplification on seismic hazard assessment is shown for the study area.
\end{abstract}

\section{Keywords}

Seismic Hazard, Peak Ground Acceleration, Response Spectra, Ground Motion, Geophysical Investigations

\section{Introduction}

Earthquakes are one of the dangerous natural hazards especially, for regions 
with moderate and high seismic activity. Earthquake hazard mitigation requires researches in many areas including geotechnical earthquake engineering. In the past few decades, significant advancement has been made to understand and develop physical and analytical modelling for aforementioned geotechnical earthquake engineering problems.

Seismic hazard maps, as spatial representations of ground motions for fixed probability levels, are significant for seismic design and seismic risk mitigation.

In addition, soil nonlinearity plays an important role. Signs of soil nonlinearity include decreased spectral ratios of surface to input motion near the dominant frequency of the soil, decreased statistical uncertainty in prediction of peak acceleration, and increased effective period of surface motion.

The nonlinearity of soil behavior is known very well, thus most reasonable approaches to provide reasonable estimates of site response are very challenging area in geotechnical earthquake engineering. Understanding of Site Response of geological materials under seismic loading is an important element in developing a well-established constitutive model. A number of different techniques have been developed for site response analysis [1].

Shear-wave velocity data has become increasingly important in evaluating site conditions for ground motion amplification. In particular, its average over the first thirty meters (Vs30) is currently the standard parameterization for addressing site-conditions.

In this paper, the $\mathrm{P}$ and $\mathrm{S}$ wave velocities together with available geotechnical parameters were used to perform a geomechanical characterization of the local site, enabling the proposition of a soil classification. It is well known that near surface $\mathrm{P}$ and $\mathrm{S}$-wave seismic velocities provide valuable information for studies of ground motion behavior, natural frequencies and the liquefaction potential under the effects of an earthquake [2].

In the manuscript, case study of complex seismic studies and site response analysis are proposed for the local site.

The study area is located in central part of Tbilisi, the capital of Georgia with latitude $41.728756^{\circ} \mathrm{N}$, longitude $44.757249^{\circ} \mathrm{E}$.

This manuscript focuses on the integration of geophysical survey for geotechnical site characterization and site-dependent seismic hazard assessment for local area. One of the most important parts of the study is evaluation of the geotechnical near-surface features of the area using refracted wave method through the acquisition, processing and interpretation of direct and shear waves, estimation physical properties of the local soil. In fact, some geotechnical parameters were estimated, such as Vs/Vp ratio, Poisson ratio, density, shear modulus, Young's modulus, common deformation modulus, etc. Then subsoil classification based on Eurocode 8 was done as well as based on Georgian building codes [3]. Taking into account all physical properties of local soil, site response analysis was done. As the final results, all obtained information was merged to each other and side dependent probabilistic seismic hazard assessment (PSHA) was done. Calculation of Probabilistic Seismic Hazard was performed using the 
Software CRISIS2015 [4]. CRISIS offers many advantages at different stages of PSHA.

\section{Geology of the Region and Local Site}

The Caucasus is a part of the Alpine folded system and is located between the Black and the Caspian Seas. The depressed zones surrounding the Greater Caucasus are found along the seas, and the Alpine folded structures are usually located between them [5].

The Caucasus region is a broad zone of deformation forming part of Alpine-Himalayan collision belt. The Greater and Lesser Caucasus Mountains roughly extend between the Caspian and Black seas, and are separated by an intermountain depression that encompasses Georgia. Geological data indicate that the formation of the Greater and Lesser Caucasus began in the Late Miocene (10 - 12 MYBP), with an average uplift of about $1.6 \mathrm{~mm}$ per year resulting in about $10 \mathrm{~km}$ uplift [6]. One hypothesis is that the Black Sea and the southern portion of the Caspian (and presumably the intermountain sedimentary basin) are remnants of back-arc basins [7].

The territory of Georgia, as a component part of the Caucasian seismoactive region, belongs to the Mediterranean belt. Its seismotectonic activity is the result of the interaction between the Arabian and Eurasian plates. In Georgia the majority of active faults are hidden (overlapped by sediments of different thickness), except some regional thrusts. They are displaced on the surface as flexures or as clusters of regional faults [8].

The city of Tbilisi lies within the Adjara-Trialeti zone, which consists of folds and faults of the northern frontal structures of the Southern Caucasus. Based on geological and geophysical investigations, there are several active faults in the Adjara-Trialeti zone, but only two of them have been identified near the city. These are located roughly along the northern and southern borders of the Adjara-Trialeti zone [9]. According to the publication [9] it was interpreted the northern branch to be dipping to the south with reverse motion, and the southern branch to be dipping north with reverse motion. Tbilisi lies roughly mid-way between these two faults (Figure 1).

\section{Seismicity of the Study Area}

Earthquake catalogue of Georgia consists of two different parts: historical and instrumental. Documentary historical catalogue stretches back to the beginning of the Christian era. The parameters of historical earthquakes are determined on the basis of the intensity data analysis [10] from contemporary documentary description of damage caused by earthquakes. For the older events the errors, in both location and date, may be substantial.

The accuracy of parameters of instrumental period is much higher. The instrumental period in Caucasus has begun in 1899, when the seismic station was installed in Tbilisi. At the beginning of the 20th century some seismic stations 


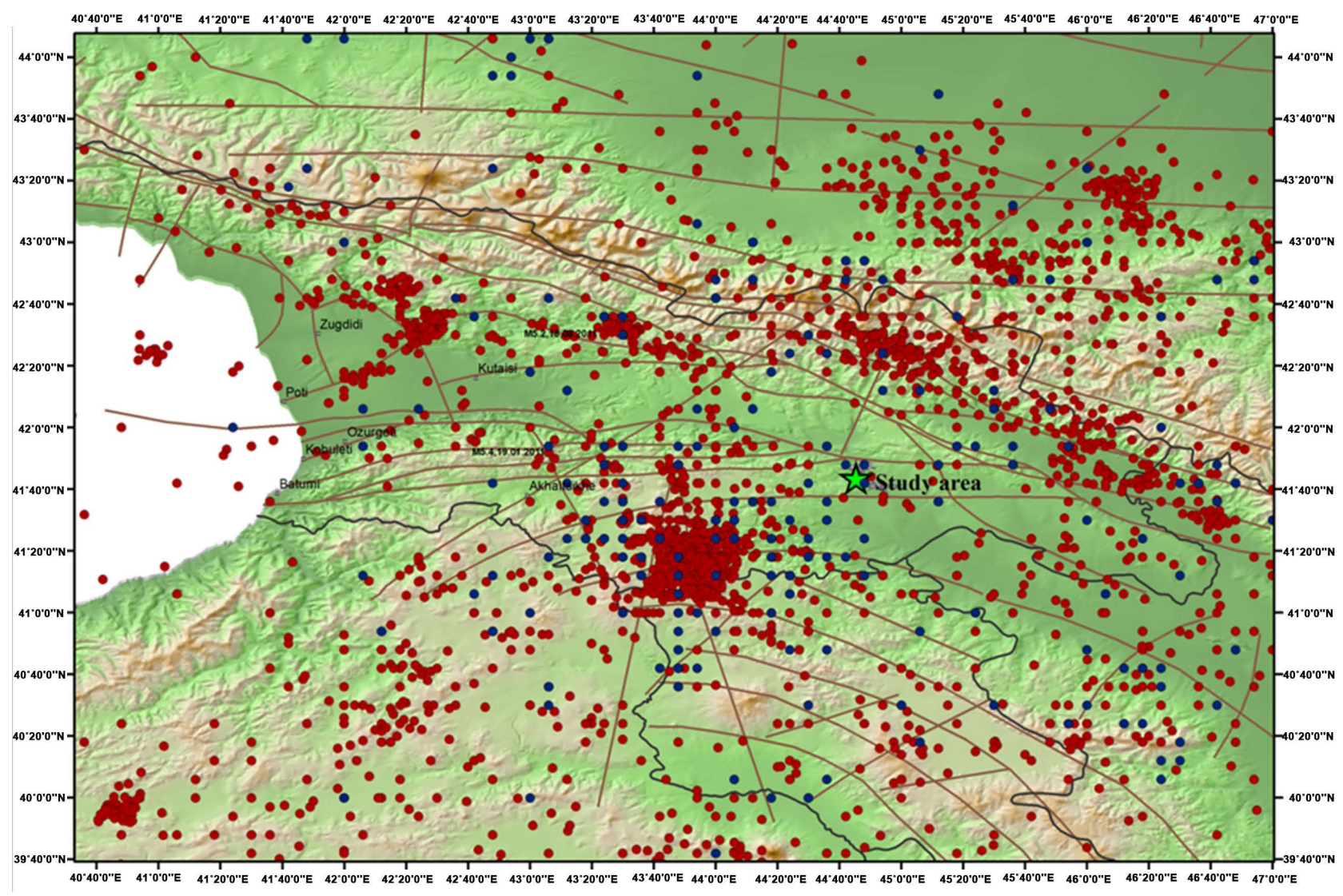

Figure 1. Seismicity map and active faults of Caucasus. Blue circles correspond to earthquakes from historical and early instrumental period, red circles to earthquakes from instrumental period $(M \geq 1.5)$.

were installed in Georgia. They were equipped by the low sensitive equipment generally of mechanical type. The data of early instrumental (till 1930) period has nearly the same quality as in the 19th century. Parameters of earthquakes mainly estimated on the basis of intensity data and therefore we consider catalogue of this period as historical (Figure 1) [11] [12] [13].

The study area is less seismically active than the Javakheti plateau or the greater Caucasus region. Figure 1 shows earthquakes of historical and early instrumental periods.

All instrumentally located earthquakes located near study area are shown in Figure 1.

Among them, an Ms = 4.2 earthquake occurred in 1969 southeast of the city, with an intensity of IV in Tbilisi. On 14 December 2000, 15:45:36.6 (GMT), an Ms $=3.5$ earthquake occurred near Tbilisi. The intensity of this earthquake in the city was quite strong. The epicenter distance was about $12 \mathrm{~km}$ and had an intensity of IV-V by MSK scale at some territory of Tbilisi. Even with this low intensity, some old buildings were damaged and some of them were collapsed. The earthquake on 25 of April in 2002 with magnitude $\mathrm{Mw}=4.6 \mathrm{had}$ an epicenter within the city, with an observed macroseimic intensity of VI-VII. Event duration was approximately 3 seconds in the city centre. The maximum horizontal 
acceleration in Tbilisi was $0.11 \mathrm{~g}$ (recorded at a distance of $8 \mathrm{~km}$ ) [14].

\section{Data and Methodology}

In the presented manuscript one engineering project location was selected as the case study. For this location high rise building construction was planned (more than 12 floors). For this location complex survey was applied such as geological and geotechnical investigations, geophysical survey (seismic profiling and downhole test in wells), seismic hazard assessment, site-dependent seismic hazard assessment. All needed data for probabilistic seismic hazard assessment such as active faults, seismic source zones, seismic catalogues and seismic parameters, ground motion attenuation models, etc. were collected and reviewed. At the end all investigations were merged and final conclusions were done.

Analysis in the presented manuscript were applied schematically is shown in Figure 2.

\subsection{Seismic Hazard Assessment}

As the first stage, all needed data for probabilistic seismic hazard assessment (PSHA) were collected and standard four stage assessment was applied [15]-[27]. Analytically, the effects of all earthquakes of different sizes, occurring at different locations within different earthquake sources, and having various probabilities of occurrence are integrated into a single seismic-hazard curve that shows the probabilities of exceeding different levels of ground shaking at the site during a specified period of time [28].

\subsection{Geophysical Prospecting}

After PSHA geophysical survey is very important to obtain local engineering-geological structure in order to study site-dependent seismic hazard analysis.

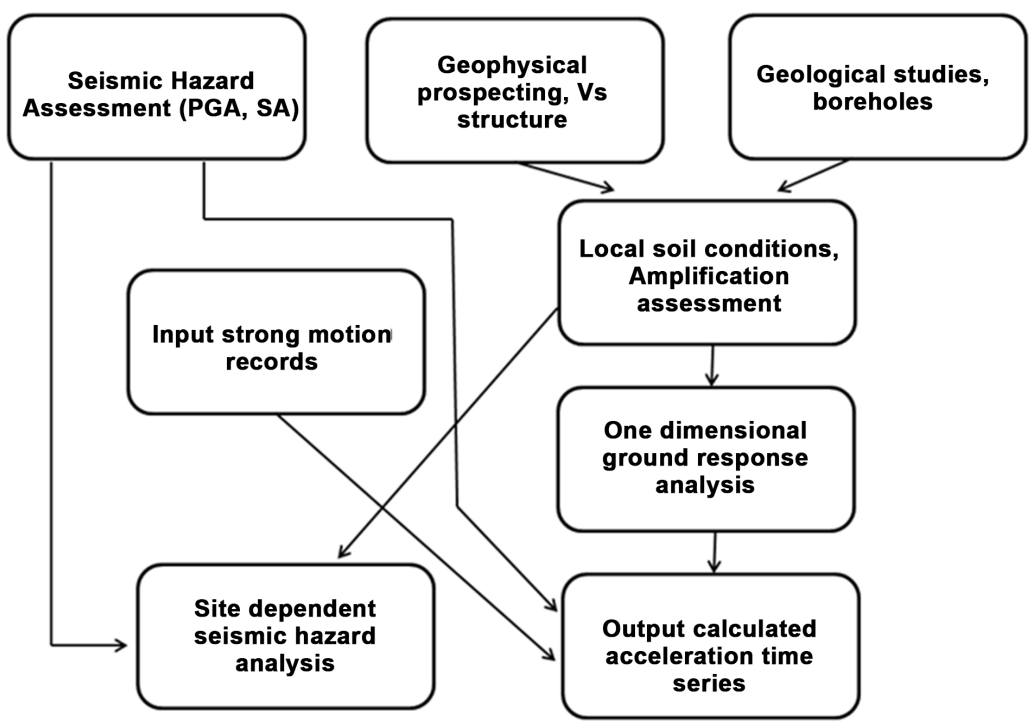

Figure 2. Scheme of analysis applied in the manuscript. 
The refracted wave method for study was used by obtaining information up to $30 \mathrm{~m}$ depth. Based on seismic profiling direct and shear wave velocities of elastic waves were observed, corresponding seismic-geological profiles were built and physical-mechanical parameters were estimated [29].

The refracted wave method gives possibility to estimate power of the top and lower layers and elastic wave velocities in those layers. The method is based on observation of the direct and shear wave velocities front offset time from source to geophones installed as a line [30].

Seismic Profiling was done using 10 and $20 \mathrm{~Hz}$ geophones, distance interval between them was $1-2 \mathrm{~m}$. Seismic waves were generated using $10 \mathrm{~kg}$ hammer shot on special plastic plate. Geophones and shots were done by Z-Z and Y-Y orientation.

Additionally, downhole tests were done in wells prepared while geological investigations. Thus, results of geophysical studies can be obtained more precisely.

Registration of elastic waves was done by 24-channel seismograph GEODE by GEOMETRICS company. Then data processing and interpretation was done, seismic profiles were built and physical-mechanical parameters were estimated. Data processing and interpretation was done using the software SeisImager by the same GEOMETRICS Company.

Using seismic refraction method shear wave velocity structure was studied up to $30 \mathrm{~m}$ depth that is very important because seismic effect depends on local soil structure [31].

\subsection{Geological Investigations}

For the site area geological and geotechnical investigations were done. Boreholes were drilled (in total 18 boreholes) and samples taken from boreholes were analyzed. As a result, detailed lithology was defined. During the investigations following physical-mechanical parameters were estimated: Density, Common deformation modulus, shear modulus, traction, and internal friction angle.

Next step is to migrate PSHA results with site amplification which is assessed based on shear wave velocities.

For site characterization and acceleration calculation EERA software was used [32].

During the earthquakes, the ground motions on soft soil sites were found to be generally larger than those of nearby rock outcrops, depending on local soil conditions [33] [34]. These amplifications of soil site responses were simulated using several computer programs that assume simplified soil deposit conditions such as horizontal soil layers of infinite extent.

The equivalent linear model represents the soil stress-strain response based on a Kelvin-Voigt model [35]. The equivalent linear approach consists of modifying the Kelvin-Voigt model to account for some types of soil nonlinearities.

- Analysis were done as following procedure;

- Input strong motion records were selected, scaled and filtered; 
- Calculation of compatible strain-reading shear wave profile and apply strain calculation procedure which at the middle of sub-layers;

- Estimation of amplification factors between two sub-layers;

- Calculation of Fourier amplitude spectrum of acceleration at the top of selected sub-layer;

- Calculation of all response spectra at the top of selected sub-layers;

- Calculation of final acceleration taking into account all steps above.

The equivalent linear model represents the soil stress-strain response based on a Kelvin-Voigt model [36].

After procedures mentioned above acceleration time series were obtained. Also, site-dependent seismic hazard analysis is done using Crisis 2015. CRISIS 2015 offers many advantages at different stages of PSHA.

\section{Results and Discussions}

In the manuscript results are presented according to the working scheme mentioned above.

First of all, probabilistic seismic hazard assessment (PSHA) is done for the rock site based on all updated information such as, tectonic settings, active faults, seismic source zones, seismic catalogues, magnitudes, distance distributions, seismic parameters, ground motion attenuation models, etc.

As a result, seismic hazard curve is built (Figure 3).

As a next stage, seismic profiling using refracted wave method was done by obtaining both direct and shear wave velocities. 6 seismic profiles (5 profiles with $46 \mathrm{~m}$ length and 1 with $23 \mathrm{~m}$ length) were done crossing each other. Also, downhole tests in 8 boreholes (which were crossing seismic profiles) were done. Due to the study area was very small; no significant changes in velocities and layer depths were detected. Thus, average velocity structure was obtained for both direct and shear waves (Figure 4).

Besides, following parameters were obtained:

Based on geological investigations structure of the study area was observed:

Layer 1-Loosed soil, sandy clay;

Layer 2-Hard and semi hard brown clay with crushed stones up to $10 \%-25 \%$;

Layer 3-Broun and grey argillite heavy cracked, with exhausted sandstone fillers.

During the geological investigations following physical-mechanical parameters were estimated: density, common deformation modulus, shear modulus, traction, and internal friction angle (Table 2).

As it seems from Table 1, Table 2, physical-mechanical parameters obtained by geological investigations and geophysical studies are in good correlations to each other.

After all above, one dimensional soil response analysis was applied.

Based on shear wave velocities soil structure was analyzed, shear modulus and unit weight was assessed (Figure 5). 


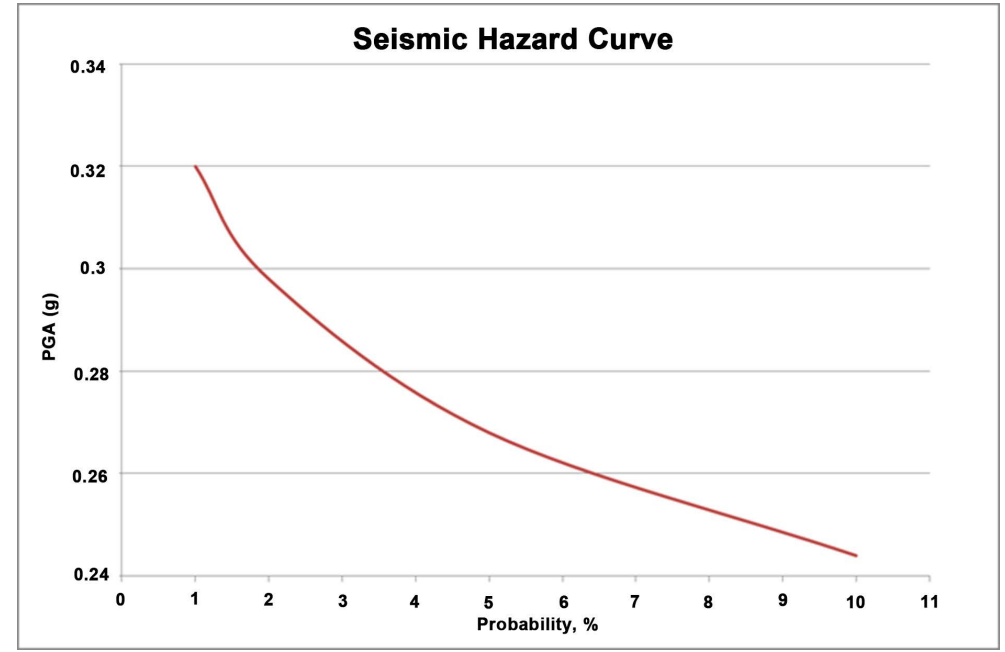

Figure 3. Seismic hazard curve for the study area.

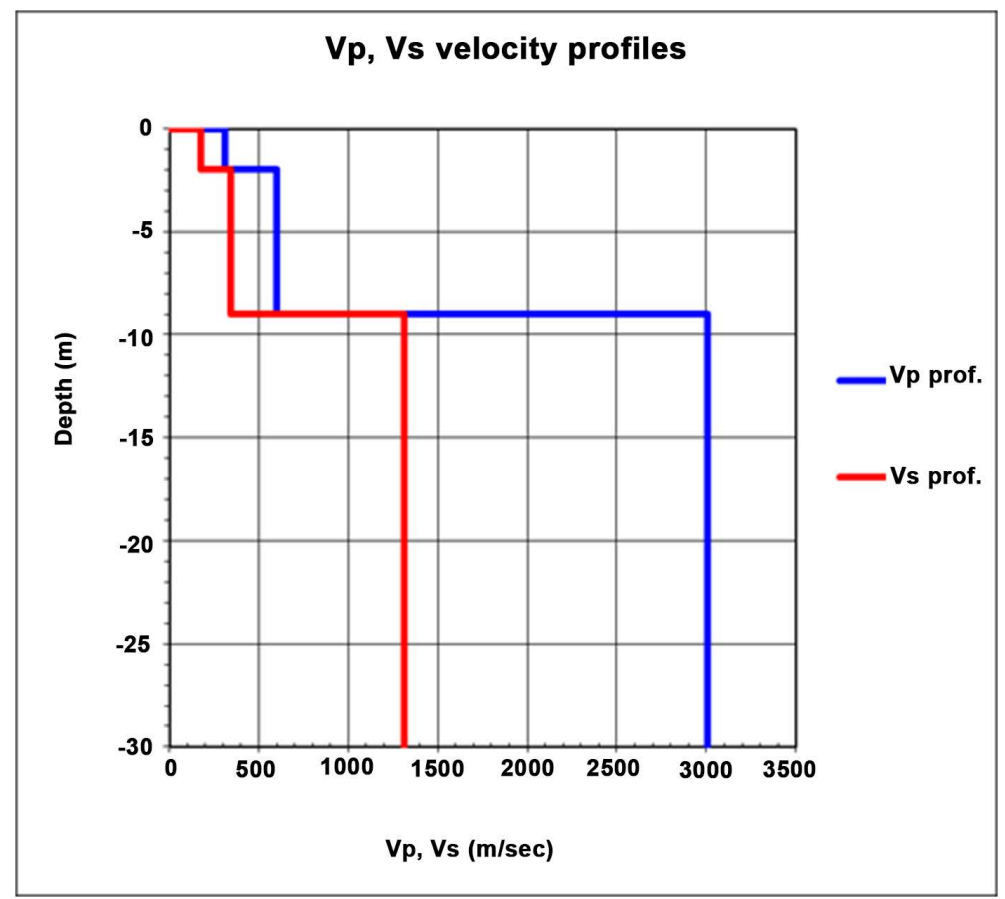

Figure 4. Average velocity profiles.

For each existing material in the local area shear modulus and damping ration is assessed (Figures 6-8).

After all above, amplification factor between two sub-layers for local soil was assessed (Figure 9).

As a next step, as an input for the software EERA, strong ground motion record from the 25.04.2002 earthquake in Tbilisi (Magnitude 4.8 Mb, MSK intensity 7, epicentre $41.77^{\circ} \mathrm{N} 44.86^{\circ} \mathrm{E}$ ) was selected. The epicentre was located at about 9.8 $\mathrm{km}$ distance from the study area. Used earthquake record was scaled and filtered (maximum frequency cut-off was selected $25 \mathrm{~Hz}$, mean square frequency - 6.547 $\mathrm{Hz}$ ), (Figure 10). 
Table 1. Physical-mechanical parameters for the study area.

\begin{tabular}{|c|c|c|c|c|c|c|c|c|c|c|c|c|}
\hline Layer $\mathrm{N}$ & Depth, m & $\mathrm{Vp}, \mathrm{m} / \mathrm{s}$ & $\mathrm{Vs}, \mathrm{m} / \mathrm{s}$ & $\mathrm{Vs} / \mathrm{Vp}$ & $\begin{array}{c}\mu_{d} \\
\text { poissoncoef. }\end{array}$ & $\begin{array}{c}E_{d} \\
\text { Youngsdyn. } \\
\text { Mod. }\end{array}$ & $\begin{array}{c}G_{D} \\
\text { Shear mod., } \\
\mathrm{MPa}\end{array}$ & $\begin{array}{c}K_{d} \\
\text { Compr. } \\
\text { Strength, } \\
\mathrm{MPa}\end{array}$ & $\begin{array}{c}\rho \\
\text { Density } \\
\mathrm{gr} / \mathrm{cm}^{3}\end{array}$ & $\begin{array}{c}D \\
\text { Common } \\
\text { defor. mod } \\
\mathrm{MPa}\end{array}$ & $\begin{array}{c}\tau \\
\text { Compr. str. } \\
\text { limit, } \mathrm{MPa}\end{array}$ & $\begin{array}{l}\text { Vs30 } \\
(\mathrm{m} / \mathrm{s})\end{array}$ \\
\hline I & 2 & 310 & 175 & 0.56 & 0.2661 & 150 & 58 & 1050.07 & 1.9 & 8.03 & 1.65 & \\
\hline II & 7 & 600 & 340 & 0.57 & 0.2635 & 580 & 231 & 4117.33 & 2 & 23.04 & 0.01 & 624 \\
\hline III & 21 & 3010 & 1310 & 0.44 & 0.3832 & 11390 & 4119 & 162527.20 & 2.4 & 1624.80 & 18.21 & \\
\hline
\end{tabular}

Table 2. Physical-mechanical parameters for the study area obtained by geological investigations using laboratory testing.

\begin{tabular}{|c|c|c|c|c|c|}
\hline Layer $\mathrm{N}$ & $\begin{array}{c}\rho \\
\text { Density, } \mathrm{gr} / \mathrm{cm}^{3}\end{array}$ & $\begin{array}{c}D \\
\text { Common defor.mod } \\
\mathrm{MPa}\end{array}$ & $\begin{array}{c}G_{D} \\
\text { Shear Modulus, MPa }\end{array}$ & $\begin{array}{c}C \\
\text { Traction, } \mathrm{MPa}\end{array}$ & $\begin{array}{c}\Phi \\
\text { Internal friction angle }\end{array}$ \\
\hline I & 1.95 & - & - & - & - \\
\hline II & 2 & 22.00 & 24.5 & 0.05 & 18 \\
\hline III & 2.38 & 1724.00 & 4079 & 4.00 & 27 \\
\hline
\end{tabular}
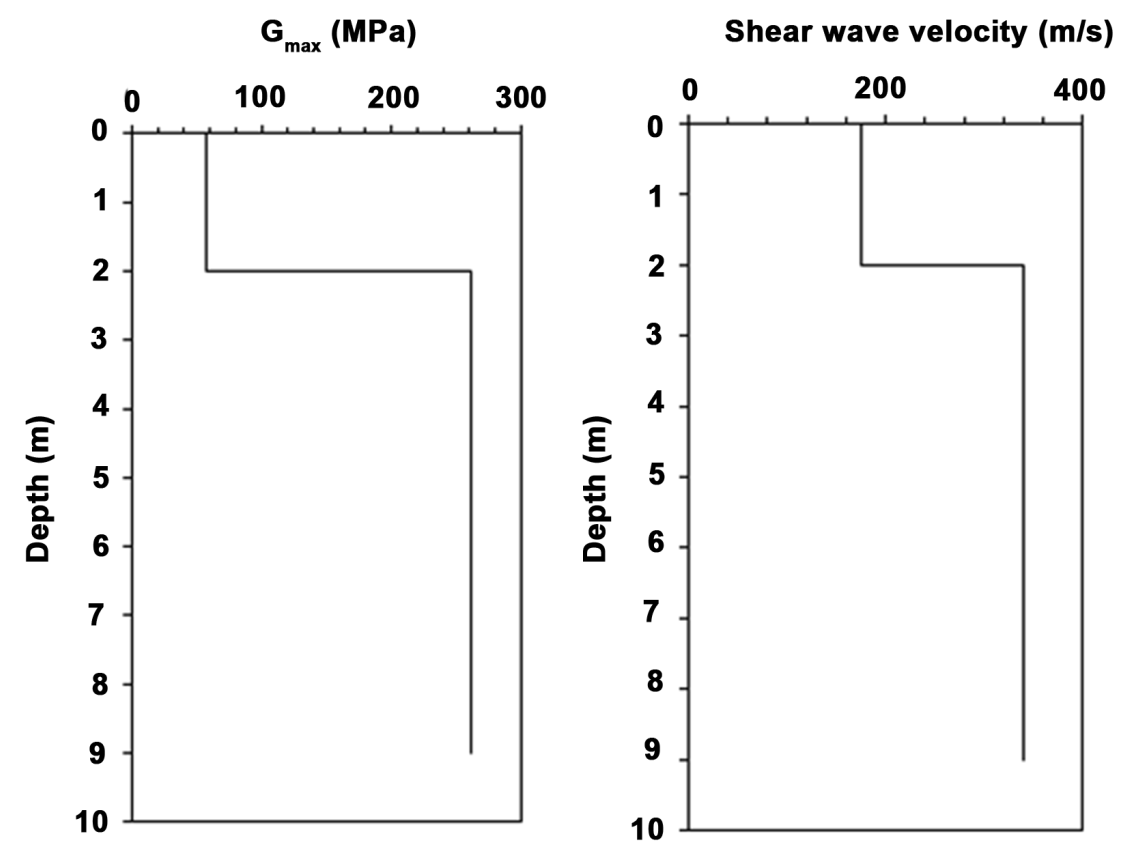

Unit weight $\left(\mathrm{kN} / \mathrm{m}^{3}\right)$

Figure 5. Shear velocities, shear modulus and unit weight for each layer material.

After applying one dimensional ground response analysis, output acceleration time series with corresponding spectral acceleration were obtained (Figure 11) which is very important input for seismic designing of the building.

At the end amplification factor was added to the probabilistic seismic hazard assessment. All data and parameters for analysis are the same as was used before for study, only local soil conditions (amplification factor) was added and calculations were done ones again (Figure 12). Calculations were done for PGA (Peak Ground Acceleration), 50 years exposure time and different probabilities. 


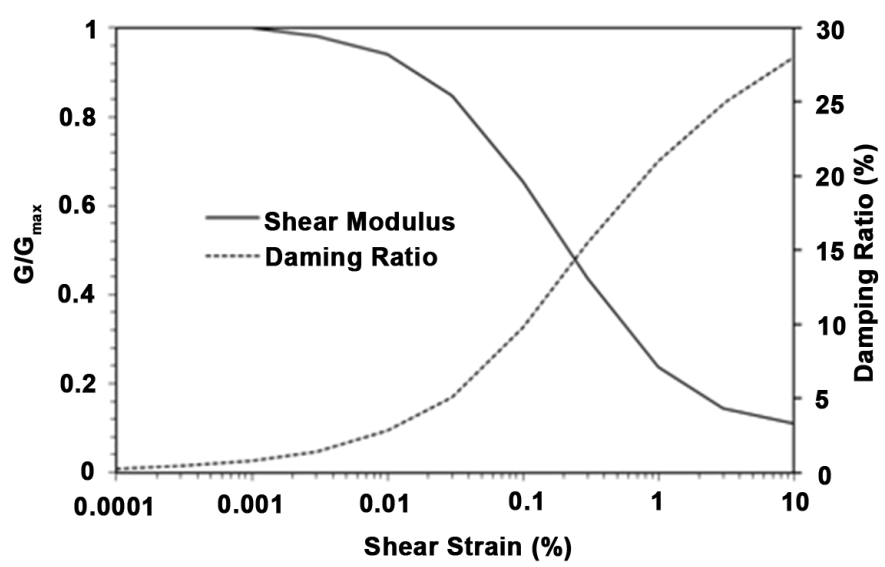

Figure 6. Shear stress and damping ratio for the layer 1 introduced by geological investigations.

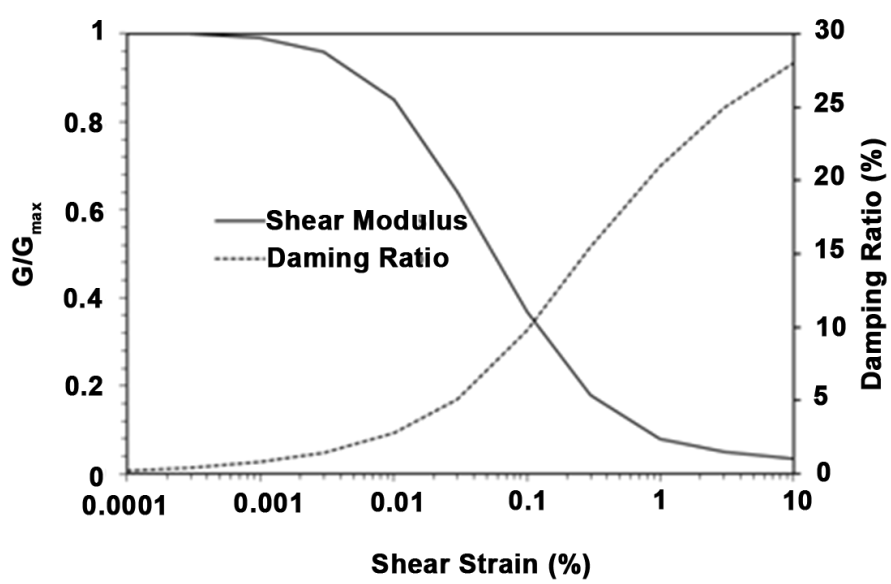

Figure 7. Shear stress and damping ratio for the layer 2 introduced by geological investigations.

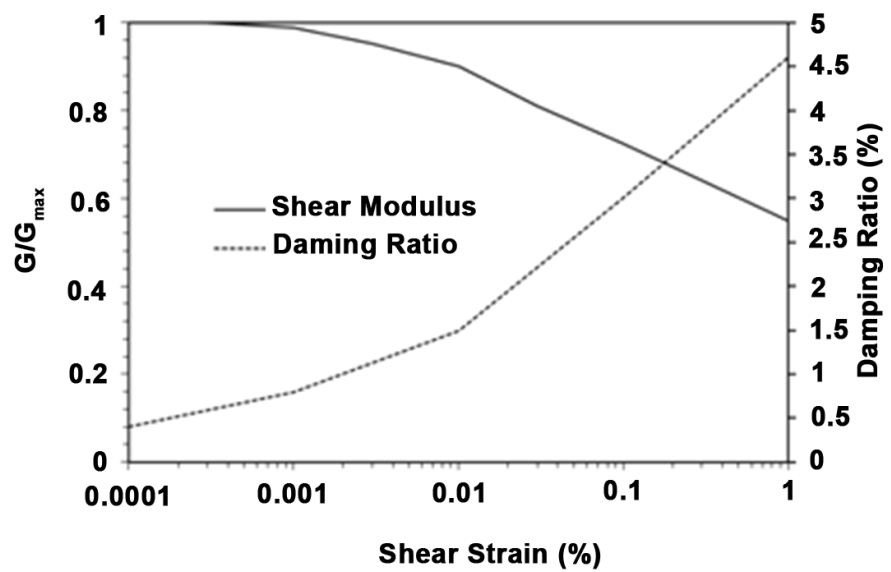

Figure 8. Shear stress and damping ratio for the layer 3 introduced by geological investigations.

As, it seems from the figure, inclusion of site amplification factor for the study area gives significant difference for PGA values. PGA values for all probabilities 


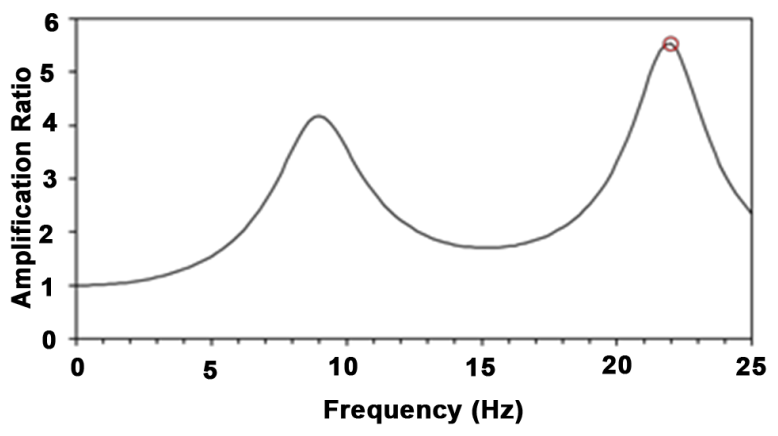

Figure 9. Amplification factor for the local soil.
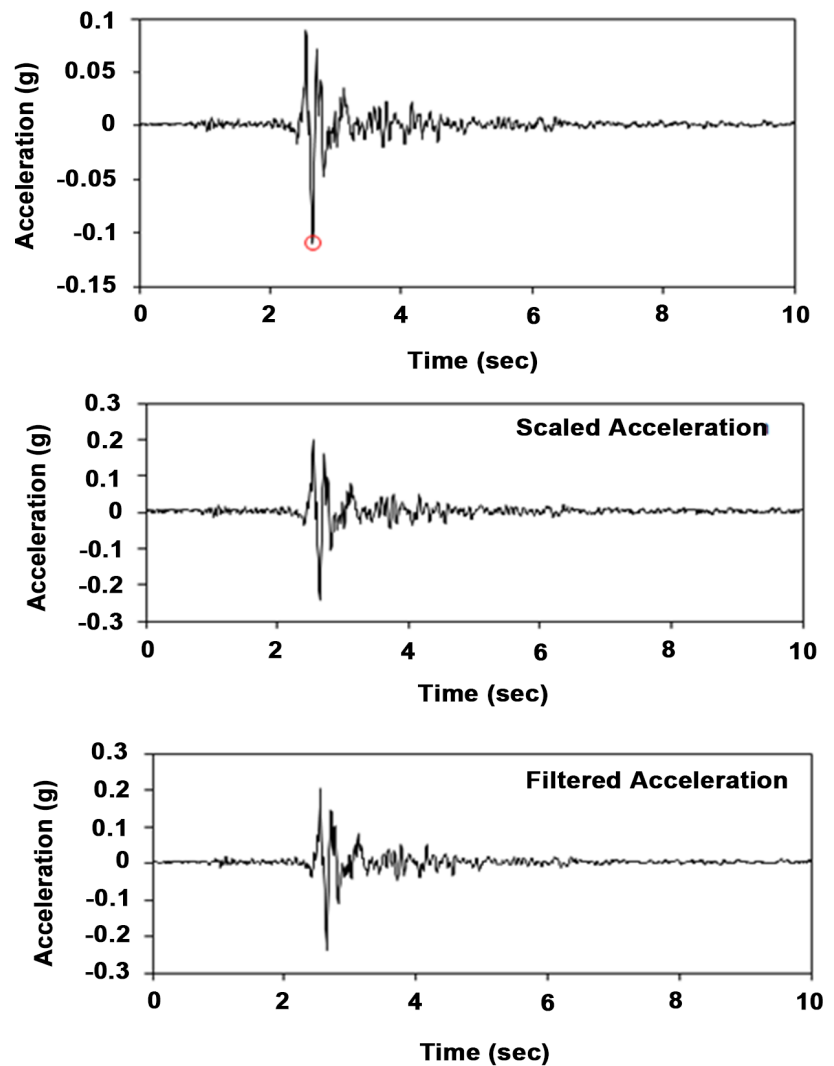

Figure 10. Earthquake acceleration record, scaled and filtered.

were increased with about $0.07 \mathrm{~g}$. This difference is caused due to the local soil structure and high amplification (average shear wave velocity up to $30 \mathrm{~m}$ depth (Vs30) for the site is $624 \mathrm{~m} / \mathrm{s}$ ). Acceleration peak value from $0.22 \mathrm{~g}$ (Figure 10) increased to $0.25 \mathrm{~g}$ (Figure 11) due to local soil conditions and amplification. Thus, to take into account detailed local soil structure for seismic design is essential.

\section{Conclusions}

Georgia is the earthquake prone country. Thus, proper seismic designating for constructions is an essential issue. For designing complex geotechnical studies is 

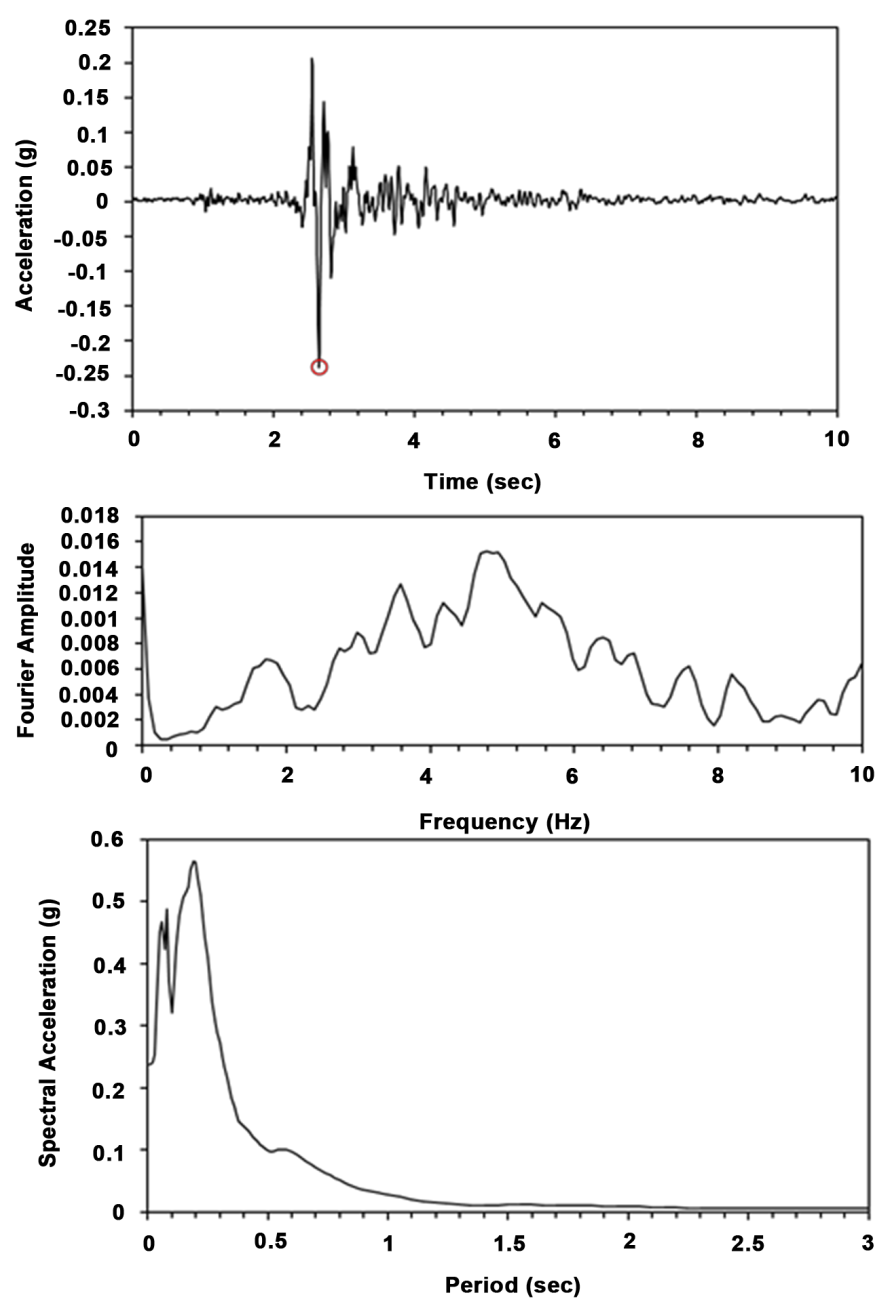

Figure 11. Acceleration record obtained after one dimensional ground response analysis.

required based on modern technologies and updated databases such as geology, earthquake catalogues, active faults, ground motion attenuation, etc.

In the presented manuscript, case study for such complex studies is presented. At the beginning, geological survey (well drilling) and geotechnical studies including laboratory tests were performed. Then geophysical profiling and downhole tests in wells were done by obtaining direct and shear wave velocities including estimation of physical-mechanical parameters. Physical-mechanical parameters obtained from geological and geophysical investigations show the good correlation to each other.

Next, probabilistic seismic hazard assessment and site-depended seismic hazard assessment were performed based on all information obtained by different studies.

PSHA was done for the rock site and on the surface taking into account local soil structure based on shear wave velocities up to $30 \mathrm{~m}$ depth. As a parameter, Peak Ground Acceleration (PGA) was selected and calculations were done for different probabilities. 


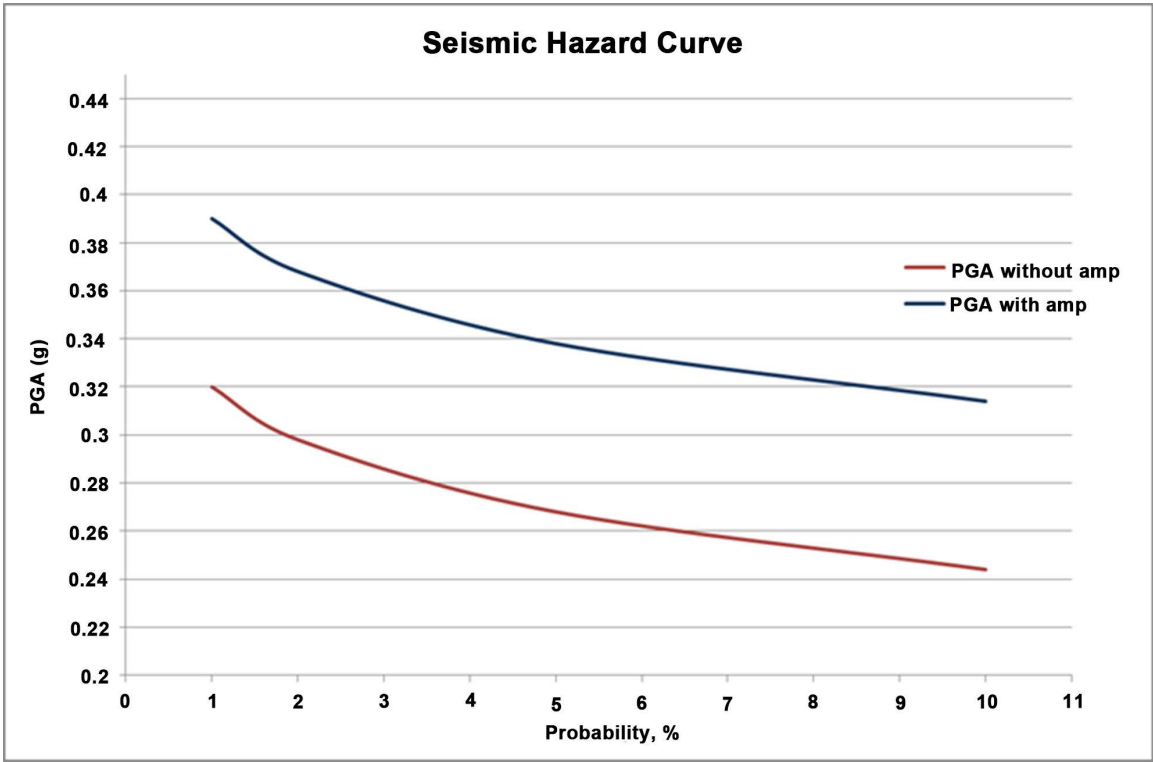

Figure 12. Seismic hazard assessment for the study area including local soil conditions.

As it was expected, after taking into account site amplification, PGA values increased with about $0.07 \mathrm{~g}$. Thus, it should be taken into account for proper seismic designing.

Acceleration peak value from $0.22 \mathrm{~g}$ (Figure 10) increased to $0.25 \mathrm{~g}$ (Figure 11) due to local soil conditions and amplification. Thus, to take into account detailed local soil structure for seismic design is essential.

\section{Acknowledgements}

We would like to thank Shota Rustaveli National science foundation (SRNSF). Results in the manuscript are obtained in frames of the project (FR/52/9-140/14) by financial supporting of the foundation.

\section{References}

[1] Arslan, H. and Siyahi, B. (2006) A Comparative Study on Linear and Nonlinear Site Response Analysis. Environmental Geology Journal, 50, 1193-2000. https://doi.org/10.1007/s00254-006-0291-4

[2] Carvalho, J., Torres, L., Castro, R., Dias, R. and Mendes-Victor, L. (2009) Seismicvelocities and Geotechnical Data Applied to the Soil Microzoning of Western Algarve, Portugal. Journal of Applied Geophysics, 68, 249-258. https://doi.org/10.1016/j.jappgeo.2009.01.001

[3] GNBC2009 (2009) Building Norms and Codes. Earthquake-Resisting Design. (In Georgian)

[4] Ordaz, M., Martinelli, F., Aguilar, A., Arboleda, J., Meletti, C. and D’Amico, V. (2015) CRISIS2015. Program for Computing Seismic Hazard.

[5] McClusky, et al. (2000) Global Positioning System Constraints on Plate Kinematics and Dynamics in the Eastern Mediterranean and Caucasus. Journal of Geophysical Research, 105, 5695-5719. https://doi.org/10.1029/1999JB900351

[6] Adamia, S., Zakariadze, G., Chkhotua, T., Sadradze, N., Tsereteli, N., Chabukiani, 
A. and Gventsadze, A. (2011) Geology of the Caucasus: A Review. Turkish Journal of Earth Sciences, 20, 489-544. https://doi.org/10.3906/yer-1005-11

[7] Jackson, J. (1992) Partitioning of Strike-Slip and Convergent Motion between Eurasia and Arabia in Eastern Turkey and the Caucasus. Journal of Geophysical Research, 97, 12471-12479. https://doi.org/10.1029/92JB00944

[8] Shengelia, I., Javakhishvili, Z. and Jorjiashvili, N. (2011) Coda Wave Attenuation for Three Regions of Georgia (Sakartvelo) Using Local Earthquakes. Bulletin of the Seismological Society of America, 101, 2220-2230.

https://doi.org/10.1785/0120100326

[9] Gamkrelidze, I., Giorgobiani, T., Kuloshvili, S., Lobjanidze, G. and Shengelaia, G. (1998) Active Deep Faults Map and the Catalogue for the Territory of Georgia. Bulletin of the Georgian Academy of Sciences, 157, 80-85.

[10] Bius, Y.I. (1948) Seismic Conditions of the Trans-Caucasus, Parts I, II, III. Tbilisi, Acad. Sci. USSR. (In Russian).

[11] Kondorskaya, N.V. and Shebalin, N.V. (1982) New Catalogue of the Strong Earthquakes of the USSR from Ancient Times through 1977. World Data Center A, Colorado, USA.

[12] Rogozhin, E., Reisner, G. and Iohanson, L. (2001) Estimation of the Seismic Potential of the Greater Caucasus and Apennines with Different Methods. In: Strakhov, V., Ed., Modern Mathematical and Geological Models in applied Geophysics, Publ. of Selected Scientific Articles, JIPE RAS, Moscow, 279-300. (In Russian)

[13] Ulomov, V.I. and Shumilina, L.S. (1998) Set of New Maps for General Seismic Zoning of the Territory of Russian Federation. Seismically Protected Construction. N4, 30-34 in Russian Ulomov V. I. and the GSHAP Region 7 Working Group; 1999: Seismic Hazard in Northern Eurasia. Annali Di Geofisica, 42, 1023-1038.

[14] Javakhishvili, Z., Godoladze, T., Elashvili, M., Mukhadze, T. and Timchenko, I. (2004) The Tbilisi Earthquake of April 25, 2002 in the Context of the Seismic Hazard of Tbilisi Urban Area. Bolletino di geofizika: Teoricaed Applckata, 45, 169-185.

[15] Ambraseys, N., Douglas, J., Sarma, S. and Smit, P. (2005) Equations for the Estimation of Strong Ground Motions from Shallow Crustal Earthquakes Using Data from Europe and Middle East: Horizontal Peak Ground Acceleration and Spectral Acceleration. Bulletin of Earthquake Engineering, 3, 1-53.

https://doi.org/10.1007/s10518-005-0183-0

[16] Cornell, A. (1968) Engineering Seismic Risk Analysis. Bulletin of the Seismological Society of America, 58, 1583-1606.

[17] Gutenberg, B. and Richter, C.F. (1944) Frequency of Earthquakes in California. Bulletin of the Seismological Society of America, 34, 185-188.

[18] Javakhishvili, Z., Varazanashvili, O. and Butikashvili, N. (1998) Interpretation of the Macroseismic Field of Georgia. Journal of Georgian Geophysical Society, 3, 85-88.

[19] Jorjiashvili, N., Yokoi, T. and Javakhishvili, Z. (2010) Assessment of Uncertainties Related to Seismic Hazard Using Fuzzy Analysis. Natural Hazards, 60, 501-515. https://doi.org/10.1007/s11069-011-0026-Z

[20] Jorjiashvili, N., Elashvili, M., Gigiberia, M. and Shengelia (2016) Seismic Hazard Analysis of Adjara Region in Georgia. Natural Hazards, 81, 745-758. https://doi.org/10.1007/s11069-016-2167-6

[21] Kramer, S.L. (1996) Geotechnical Earthquake Engineering. Prentice-Hall International Series in Civil Engineering and Engineering Mechanics, Prentice-Hall, Upper 
Saddle River, 653.

[22] McGuire, R.K. (1995) Probabilistic Seismic Hazard Analysis and Design Earthquake: Closing the Loop. Bulletin of the Seismological Society of America, 85, 1275-1284.

[23] McGuire, R.K. (2004) MNO-10, Seismic Hazard and Risk Analysis. Earthquake Engineering Research Institute, $240 \mathrm{p}$.

[24] Musson, R. (1999) Probapilistic Seismic Hazard Maps for the North Balkan Region. Annals of Geophysics, 42, 1109-1124.

[25] Smit, P., Arzumznian, V., Javakhishvili, Z., Arefiev, S., Mayer-Rosa, D., Balassanian, S. and Chelidze, T. (2000) The Digital Accelerograph Network in the Caucasus. In: Earthquake Hazard and Seismic Risk Reduction, Kluwer Academic Publishers, Dordrecht, 109-118. https://doi.org/10.1007/978-94-015-9544-5_12

[26] Wells, D. and Coppersmith, K. (1994) New Empirical Relationships among Magnitude, Rupture Length, Rupture Width, Rupture Area, and Surface Displacement. Bulletin of the Seismological Society of America, 84, 974-1002.

[27] Youngs, R.R. and Coppersmith, K.J. (1985) Implications of Fault Slip Rate and Earthquakes Recurrence Models to Probabilistic Seismic Hazard Estimates. Bulletin of the Seismological Society of America, 58, 939-964.

[28] Balassanian, S., Ashirov, T., Chelidze, T., Gassanov, A., Kondorskaya, N., Molchan, G., Pustovitenko, B., Trifonov, V., Ulomov, V., Giardini, D., Erdik, M., Ghafory-Ashtiany, M., Grunthal, G., Mayer-Rosa, D., Schenk, V. and Stucchi, M. (1999) Seismic Hazard Assessment for the Caucasus Test Area. Annali Di Geofisica, 42, 1139-1151.

[29] Bery, A.A. and Saad, R. (2012) Correlation of Seismic P-Wave Velocities with Engineering Parameters (N Value and Rock Quality) for Tropical Environmental Study. International Journal of Geosciences, 3, 749-757. https://doi.org/10.4236/ijg.2012.34075

[30] Mohamed, A.M.E., Abu El-Ata, A.S.A., Abdel Azim, F. and Taha, M.A. (2013) Site-Specific Shear Wave Velocity Investigation for Geotechnical Engineering Applications Using Seismic Refraction and 2D Multi-Channel Analysis of Surface Waves. NRIAG Journal of Astronomy and Geophysics, 2, 88-101. https://doi.org/10.1016/j.nrjag.2013.06.012

[31] Anbazhagan, P. and Sitharam, T. (2008) Site Characterization and Site Response Studies Using Shear Wave Velocity. Journal of Seismology and Earthquake Engineering, 10, 53-67.

[32] Bardet, J.P., Ichii, K. and Lin, C.H. (2000) EERA, A Computer Program for Equivalent Linear Earthquake Site Response Analysis of Layered Soils Deposits. University of Southern California, Los Angeles.

[33] Seed, H.B. and Idriss, I.M. (1970) Soil Moduli and Damping Factors for Dynamic Response Analysis. Report No. UCB/EERC-70/10, Earthquake Engineering Research Center, University of California, Berkeley, December, $48 \mathrm{p}$.

[34] Seed, H.B., Wong, R.T., Idriss, I.M. and Tokimatsu, K. (1986) Moduli and Damping factors for Dynamic Analyses of Cohesionless Soils. Journal of the Geotechnical Engineering Division, 11, 1016-1032. https://doi.org/10.1061/(ASCE)0733-9410(1986)112:11(1016)

[35] Schnabel, P.B., Lysmer, J. and Seed, H.B. (1972) SHAKE: A Computer Program for Earthquake Response Analysis of Horizontally Layered Sites. Report No. UCB/ EERC-72/12, Earthquake Engineering Research Center, University of California, 
Berkeley, December, 102 p.

[36] Germoso, C., Aguado, J.V., Fraile, A., Alarcon, E. and Chinesta, F. (2016) Efficient PGD-Based Dynamic Calculation of Non-Linear Soil Behavior. Comptes Rendus Mécanique, 344, 24-41. https://doi.org/10.1016/j.crme.2015.09.002 